The Hon. Walter Rothschild emphasised the point that any society or individual proposing such an important change as that proposed by the German Zoological Society ought, if they wanted serious consideration at all, to put their meaning in absolutely clear and unequivocal language. He stated that the time quoted, "twelve" years, as being sufficient to judge of the need of the "law of priority" was absurd, as it would take at least two generations for the law in question to settle nomenclature in general, and at least one generation before we could judge of its effects. Mr. Rothschild also stated that a progressive list of exceptions to that law, namely, one to be augmented from congress to congress, would lead to utter chaos. He was opposed to any exceptions whatever, but would be willing to see, in cases where confusion was likely to arise, that names for a long time employed for one genus or species, and which under the rules must be transferred to another, should be dropped altogether, and that names differing only in one letter from any already in use should be treated as inadmissible. He was also in favour of using larval names, and those founded on a single phase only, being used in that sense only, and not under the law of priority used for the adult in another phase.

Finally, it was resolved-that plenary power is herewith conferred upon the international commission in zoological nomenclature acting for this congress to suspend the règles as applied to any given case, where in its judgment the strict application of the règles will clearly result in greater confusion than uniformity, provided, however, that not less than one year's notice shall be given in any two or more of the following publications, namely, Bulletin de la Société Zoologique de France, Monitor Zoologica, Nature, Science (N.Y.), and Zoologischer Anzeiger; that a question of the possible suspension of the règle as applied to such cases is under consideration, thereby making it possible for zoologists, particularly specialists in the group in question, to present arguments for and against the suspension under consideration; and provided also that the veto of the commission is unanimously in favour of suspension if not less than two-thirds be present. The commission is hereby instructed to report the facts to the next succeeding international congress.-It was also resolved "That the congress fully approves of the plan that has been inaugurated by the commission of conferring with special committees from the special groups involved in any given case, and that it authorises and instructs the commission to continue and extend their policy." Altogether, the conclusions arrived at appear thoroughly satisfactory, especially as the plenary power of the commission is very adequately safeguarded.

The invitation of the Government of Hungary to hold the congress of 1916 in Budapest was accepted, and Prof. Hovarth, of Budapest, was elected president.

NO. 2268, VOL. 9I]

\section{THE INTERNATIONAL CONGRESS OF} HISTORICAL STUDIES.

T HE members of the International Congress of Historical Studies have been holding their meetings in London, under the presidency of $\mathrm{Mr}$. James Bryce, who was, however, unfortunately absent throughout the proceedings. Five years ago, the congress held very successful meetings in Berlin, and ten years ago it assembled under favourable auspices in Rome. If the London meeting has attracted less notice in the country of its assembling than the two preceding ones, it has none the less produced some excellent papers, and it must be accounted a real loss to the general public that the very faulty organisation of the congress, combined with our insular aloofness and the ignorance of modern languages which is an accepted item of English education, has prevented the meetings from receiving their due share of attention.

The congress has covered so large a field of historical studies that any general survey of its deliberations would be impossible in this place. It has discussed the philosophy of history and the nistory of historical studies, while other sections have met daily to exchange views on Egyptian, classical, Byzantine, and Oriental history, as well as on matters pertaining to military, naval and colonial, religious and ecclesiastical, legal and economic, mathematical and scientific, studies.

The President of the Board of Education (Mr. J. Pease) directed attention to the frequent connection that has existed in England between history and politics, citing the names of Clarendon, Gibbon, and Macaulay; and, at the present time, of Bryce and Trevelyan. The advantages of such a connection may perhaps be questioned. From it has resulted the habit of treating history as a branch of politics rather than of considering politics as a department of history. The current text-book treatment of the English civil war and the American revolution-to give but two instances-has probably suffered much in its accuracy from the fact that the principal English historians have been primarily Whig politicians. To the popular conception of the politician as the sufficient and efficient historian, we may perhaps attribute the neglect by successive Governments of the marvellous series of records-the admiration and envy of other European nations, and the best material for history-which belong to this nation. No one knows better than Prof. C. H. Firth, who dealt with the subject of English records, how badly kept, how inaccessible, how uncalendared, are a great proportion of our English public documents.

It was entirely characteristic of the English politician-historian that, at the Oxford dinner, Lord Morley of Blackburn should warn his hearers against laying too much stress on research in diplomatic archives and parish registers, and should remind his audience that, fortunately or unfortunately, sentiment and prejudice have had far more to do with the making of history than reason and precedent. 
The president's address, read in his absence by Dr. A. W. Ward, of Peterhouse, contained references to the importance of recent discoveries regarding the early Mediterranean civilisations, and laid stress on the value of modern critical ethno$\log y$ for the correct understanding of the foundations of present-day movements in Europe; while Mr. D. G. Hogarth's paper on Hittites and the Hittite civilisation showed that a beginning has been made in attacking an outstanding problem bearing on the same subject. Prof. E. Bernheim spoke of history as a record of the variation of intellectual viewpoint at different epochs of time. Prof. von Gierke dealt with the evolution of the idea of the right of a numerical majority to control the government of a country. Prof. Pirenne gave a suggestive account of the stages in the growth of capitalism from the twelfth to the nineteenth centuries, and described the change from mere subsistence industry and husbandry to the creation of capitalism as an engine by which the advancing intelligence can obtain an increase in knowledge, in material resources, and in control over the forces of nature.

In the subsection devoted to the exact sciences, natural history, and medicine, papers were read by Sir Clifford Allbutt on Palissy, Bacon and the revival of natural science; by Prof. Loria on mathematics in Great Britain; by Prof. Silvanus Thompson on the history of the compass card; by Prof. H. H. Turner on Aristarchus of Samos, and by Mr. Rouse Ball on Newton's Principia and also on magic; Dr. Norman Moore gave an account of the Royal College of Physicians, Prof. L. C. Miall illustrated seventeenth-century research by the life of Peiresc, and Mr. W. C. D. Whetham read a paper on the historical method in natural science.

\section{PUBLIC VETERINARY SERVICES.}

A DEPARTMENTAL Committee on the Public A Veterinary Services was appointed last August by Mr. Runciman to inquire into the requirements of the public services with regard to the employment of officers possessing veterinary qualifications, and to consider whether any further measures can with advantage be adopted for the selection and training of students with a view to such employment. The committee, the report of which has recently been published (Cd. 6575), consisted of Sir A. Hopkinson (chairman), Sir T. H. Elliott, Sir T. W. Holderness, Mr. H. J. Read, and Major G. F. MacMunn. In October Sir T. W. Holderness resigned, and Mr. F. C. Drake succeeded him.

In all twenty-one witnesses were examined, together with a number of written statements of representatives of self-governing Dominions and universities who for various reasons were unable to attend in person. Evidence was given on behalf of the Departments employing veterinary officers, viz., the Colonial Office, India Office, War Office, and the Board of Agriculture and Fisheries; also on behalf of the five veterinary colleges, the examining and diploma-granting body NO. 2268, VOL. 9I] (the Royal College of Veterinary Surgeons), and various British universities.

After considering the present system of veterinary education, the committee is of opinion that the standard appears sufficient for the purposes of private practice, but not for the public services, for research and administrative work. The army veterinary department has no difficulty in finding suitable candidates, and, moreover, the first two years of the young officer's service are devoted to the improvement of his education, and to training him for his future work,

The demand for the other public services of veterinary officers has increased, and will almost certainly increase still further. Already great difficulty has been encountered in procuring suitably trained men for the posts, alike at home, in the Colonies, and in India. The most important steps to be taken to improve the quality and quantity of candidates are (I) to encourage a la1ger number of young men who have continued their general and scientific education beyond secondary-school age to enter the veterinary profession; (2) to provide for men who have qualified as veterinary surgeons increased facilities to extend their knowledge, more especially in the direction of specialisation in one branch of veterinary science; and (3) to improve the system of notifying vacancies.

With these objects in view the committee recommends that: Students possessing a suitable science degree should be exempted from one of the four years at present required for veterinary qualifications; that twelve scholarships should be offered each year of the annual value of $80 l$. each, tenable at a veterinary college for three years, with a view to encourage a number of men who have received a good scientific education to enter the veterinary profession; scholarships of an annual value of not less than rool. and not exceeding ${ }^{5} 5$ ol. should be offered each year to enable qualified veterinary surgeons to undertake advanced study and laboratory work at suitable institutions at home or abroad, where special facilities for such studies exist. The committee further recommends that increased State aid should be given to institutions devoted to veterinary education, the efficiency of which is of great importance to the State. It is of opinion that the Royal College of Veterinary Surgeons " is performing a work of great national importance, and that its efforts to maintain a. high standard of veterinary education in this country are worthy of every encouragement."

\section{NOTES.}

THE International Congress of Zoology at Monaco and that of Geography at Rome are over, but another interesting meeting of representatives of the nations took place on April 5, at the Zoological Station, Naples. The occasion was the unveiling of a memorial tablet to the illustrious founder of the station, Prof. Anton Dohrn. The tablet, in bronze, which has been fixed above the fountain on the north side of the 